\title{
Challenges and Opportunities in Using the Internet to Realize Democracy in Egypt
}

\author{
Nahed Amin Azab \\ Management Information Systems, Department of Management, \\ The American University in Cairo, Egypt
}

\begin{abstract}
There is a widespread belief that the Internet provides real opportunities for democratization and political transformation, especially in authoritarian regimes characterized by a strong restriction on freedom of speech and expression and inability of civic engagement and participation. Such role has been clearly witnessed with the rise of the Arab spring in general, and in Egypt in particular. During the 18 days of the Egyptian revolution starting on 25th January 2011, and afterwards, the Internet proved to be an important tool in mobilizing people, coordinating between protestors and documenting and publishing facts that occurred on the ground during the revolution. However, such optimistic view cannot be supported unconditionally due to several reasons related to the uniqueness of each country. This paper therefore attempts to critically examine the potential of the Internet on the political transformation in Egypt taking into consideration a full context covering economical, political, technological and social dimensions. Studying these various aspects would highlight the challenges and opportunities that affect the Internet in changing the political situation during the transitional period the country is going through.
\end{abstract}

Keywords: Internet, Politics, Democracy, Arab Spring, Developing Countries, Egypt.

\section{Introduction}

There is growing evidence that the Internet has an influence on identity development and on civic communication and participation (Wyn et al., 2005; Metcalf, 2008). Beside easy access to the news, the Internet allows people to read others' reviews and to send feedback comments on the news they read. Citizens' participation was more encouraged due to the emergence of 'Web 2.0' technologies, such as blogs, podcasts and social networking websites, which blurred the boundaries between publisher and reader. Any user has the chance to be a message receiver or sender during any given communication cycle (Williams, 1998, Boczkowski, 2004). By enabling individuals to create and publish content, such technologies promote collaboration, ownership, empowerment (Boulos and Wheelert 2007; Christensen et al., 2002; Crespo 2007) and the ability to express opinions and be heard. Boulos and Wheelert (2007) and Lefebvre (2007) argue that this in turn could result in increasing flexibility and democracy.

Seeking to reach democracy, the youth who initiated the Arab spring, especially in Tunisia, Egypt and Yemen, have relied on the Internet in disseminating news and philosophies of their revolutions, and in mobilizing people in their countries. Such initiatives were recognized and appreciated worldwide as some of revolutions' leaders were nominated for peace prizes, such as Nobel from Switzerland, Sakharov by the

Copyright (C) 2012 Nahed Amin Azab. This is an open access article distributed under the Creative Commons Attribution License unported 3.0, which permits unrestricted use, distribution, and reproduction in any medium, provided that original work is properly cited. Contact author: Nahed Amin Azab E-mail: Nazab@Aucegypt.Edu 
European parliament and Anna Politkovskaya from Russia. The role played by the Internet in the Egyptian revolution triggers the need to question whether it would contribute negatively or positively in reaching democracy during and after this transitional period.

This paper starts by reviewing the literature discussing the relation between the Internet and democracy. Next, the paper presents different means to use the Internet in politics, and examines the applicability of these means in Egypt and their potential in assisting the country in its path towards democracy at a crucial phase during which the first democratically elected parliament has just held its opening session on the $23^{\text {rd }}$ of January, only 2 days before the passing of the first year of the Egyptian revolution.

\section{The Internet and Democracy}

There is a growing controversy related to the ability of the Internet in assisting developing countries in fostering democracy. Some researchers see that the Internet can contribute to a great extent into such direction. For example, Milner (2006) argues that Internet capabilities (easy, broad, cheap access and sharing of information) allow for building and mobilizing opposition groups, which impose threat on autocratic regimes. Being aware of that strong effect of the Internet, such regimes do not encourage Internet adoption compared to democratic ones (Norris, 2001).

Furthermore, the Internet has the potential to realize the concept of the "public sphere" as defined by Jürgen Habermas (1974): a place where communities could jointly form public opinions in an environment removed from the government or economy. On the other side, Downey and Fenton (2003) quote the expression "bad civil society" from Chambers and Kopstein (2001) described as being capable of creating a counter public sphere that could alter democratic public dialogue. Lunat (2008) notes that the Internet leads in several cases in developing countries to promoting violence due to the 'fragile structure' of public spheres in these communities. In fact, several reasons affect negatively the Internet potential in promoting democracy in developing countries: (i) limited Internet accessibility by many sectors in the society (Khiabany, 2009) and its availability to extremists (Dean (2003); (ii) absence of well established and sustainable online political entities (Lunat, 2008); (iii) being an additional media type, the Internet is usually in line with the existing political status enabling traditional authorities to increase their political power (Papacharissi, 2002); (iv) tracking and censorship by existing (and most probably autocratic) regimes (Albirini, 2008). As such, Albirini (2008) criticizes the optimistic view that assumes that the Internet can modify the dictatorial structure of developing countries describing this as an 'illusion'.

\section{Internet Political Channels}

Several World Wide Web applications encouraged citizens to engage into politics, especially online newspapers, social network sites (e.g., Facebook, Twitter, MySpace, LinkedIn, etc.) and blogs. The Internet made a remarkable shift in the newspaper industry since the creation of the first non-print in 1995. The evolution of online papers on the web has provided a window for the emergence of new content-creation regimes, and allowed the examination of broader patterns in the construction of information on the Internet, multimedia developments being an example (Boczkowski, 2004; Molina, 1997). Starting from 1995, the Web proved to be the "electronic publishing environment of choice" for publishing newspapers (Garrison, 1997; Martin and Hansen, 1998; Molina, 1997). More than 175 US dailies were published on the Web by the end of 1995 , growing to over 750 three years later (Newspaper Association of America, 1998; Editor and Publisher, 1996). In a survey of US online newspapers, Peng et al. (1999) conclude that the top three reasons for publishing on the Web versus other options are (1) availability of a large number of 
readers worldwide (57\%), (2) ease of publishing (27\%), and (3) superior graphical presentation (15\%).

Most newspapers and news portals currently provide links to several social networks as an extended channel to foster more participation among their readers. Since the Howard Dean campaign on Facebook in 2004, the Internet was recognized as a powerful tool in gauging the interest and opinion of the public in the political process, as well as communicating efficiently with supporters (Westling, 2007). The most widely used social networking site is Facebook, which covers an increasing and broader number of networks (academic institutions, cities, organizations, clubs, etc.) of different geographic and ideological aspects, reaching more than 500 million members in 2010 (Facebook Press Room, October 2010).

Facebook provides political actors with an efficient and inexpensive tool to disseminate their messages to a wide audience, to mobilize and organize thousands of supporters and to measure public opinion. One of the main causes of the success of Barack Obama's presidential campaign in 2008 was the resourceful and creative use of Facebook by his then-campaign-manager David Plouffe, pulling out young, disenfranchised voters to the polls. Even before Barack Obama announced his candidacy for president, the Facebook group "Barack Obama for President in 2008" had accumulated over 50,000 members. Another group, "Barack Obama (One Million Strong for Barack)" gathered 200,000 members in less than three weeks (Goldfarb, 2007), reaching 325,000 by April 2007. Obama also had strong presence on other social websites including MySpace, Twitter, MyBatanga, MiGente and AsianAve. Obama's opponent John McCain did not give similar focus to social networks and had fewer than 200,000 supporters on Facebook (Terhune, 2008). The increasing role of Facebook in presidential campaigns can clearly be seen by noting that Howard Dean ended up with over
190,000 members in his Meetup.com group at the end of his 2004 presidential primary campaign (Trippi, 2004), versus more than 3 million supporters for Obama (DWSMG, 2008).

In addition to online newspapers and social network websites, political blogs are seen as an increasingly powerful form of journalism on the Internet (Farrell and Drezner, 2008), expanding media freedom (Coleman, 2005) and shaping democracy outside the mass media and conventional party politics (Gillmor, 2003). They should be seen as democratic listening posts, enabling us to pick up signals of subjective expression. Blogs were recognized in 1997 with the launching of Scripting News, a website developed by Dave Winer (Schiano et al., 2004) (dubbed the "Father of Blogging") (BBC News, 2007), recording his views on different topics, and the longest-running blog on the Internet in 2003 (Gillmor, 2003). Blogs are gaining a growing popularity among Internet users, particularly political ones, which receive thousands of hits daily (Schiano et al., 2004). Starting with the 2004 US Presidential campaign, blogs were clearly perceived by candidates, political parties and mainstream media as a powerful tool to monitor, publish, discuss, host breaking news and even create self-owned blogs (Adamic, 2005; Bahnisch, 2006; Bichard, 2006; Carlson, 2007; Kerbel and Bloom, 2005; Stromer-Galley \& Baker, 2006; Trammell, 2006; Baumer, 2010). There are several reasons that drive Internet users to create blogs: responding to readers' requests, updating others about their lives and activities, thinking by writing, looking for others' feedback, conveying opinions and convincing others, or merely reducing tension (Nardi et al., 2004). One of the main advantages of blogs lies in their asymmetric and "non-intrusive" nature, unlike emails or instant messages. This reduces the temper and intensity of interaction (Clark and Brennan, 1991). Feedback can be through blogs, other media, or face-to-face communication, all after some time has elapsed, which allows for deeper and less 
emotional interaction. Furthermore, people read blogs because they find up-to-date, genuine and sincere opinions compatible with their views (Johnson et al., 2007), independency and freedom in expressing beliefs, (Bruns, 2006; Lasica, 2002) as compared to the controlled and balanced nature, which characterizes media corporations (Metzger et al, 2003). Furthermore, politically interested Internet users see that blogs are more credible than other online sources (Johnson et al., 2007).

\section{Internet and Politics in Egypt}

Even though the Internet started in Egypt in 1993, interest in using the Internet in politics has become clearly apparent since 2008, when a Facebook page was created by the group "6th of April Youth", to call for a labor strike against price hikes (Azab, 2012). Despite limited use of the Internet by political candidates to express their views and to interact with voters, a number of users head towards the Internet for other reasons: seeking political facts, commenting on political news and events, attempting to bring about partial change (Awad, 2010), gathering political views through polls and surveys and supervising the regime through publishing and disseminating corruptions and violations of human rights.

Top Egyptian newspapers (e.g., AlAhram, AlMasryAlyoum, AlShorouk, AlDostor, etc.) have created not only e-newspapers publishing the same content as their corresponding traditional ones, but also their Internet portals to provide continuous updated content around the clock. Social networks, especially Facebook and Twitter, are used extensively in politics in Egypt. One of the most influential Facebook pages is "We are All Khaled Said", which was created before the revolution on 6 June 2010. At that date, Khaled Said, a 28 year-old young man from Alexandria was found dead, with a common belief that he was tortured to death by two policemen (Abdellah and Blair, 2010). The page was created bearing his name, and attracted 4000 members to join in the first hour (ElShorouk Newspaper, 11 June 2010), with an increase of 1000 members each hour (Adel, 2010a). Several activists uploaded videos of the incident's witnesses stating evidences contradictory to those expressed by the Ministry of Interior (ElShorouk Newspaper, 15 June 2010). As a result, the Attorney General was compelled to order the extraction of Said's body and assign a committee to conduct a re-autopsy in order to explain the cause of death and injuries on the body (AbouElMaaref, 2010; Fouad et al., 2010). A remarkable online presence on social networks was also attributed to Dr. Mohamed ElBaradei, who was a prospect candidate "posing the most serious challenge" for the presidential position in Egypt in 2010 (BBC News, 2010; Broad, 2010). ElBaradei raised hope to the youth posing a possibility to commit political change through using Twitter and Facebook as channels for communications with citizens. "We are All Khaled Said", "6th of April Youth" and "Mohamed ElBaradei" Facebook pages played an important role in initiating the Egyptian revolution (Ghuitas, 2011). As for blogs, many of them were recognized in expressing views opposed to existing regimes before and after the revolution (e.g., Wael Abbas, Mohamed Abdel Fattah, Michael Nabil, and Alaa Abdel Fattah). Some political blogs not only express ideas, but also include videos and photos to support them.

Realizing the increasing interest and position of the Internet in politics before and during the revolution, the current regime that started ruling in 11 February just after the 18-days revolution, is using Facebook to convey messages and interact with the Egyptian society and to obtain its feedback through reviews and polls.

\section{Discussion and Conclusion}

The previous section shows that the Internet different channels are used extensively in politics in Egypt. However, they are still insufficiently exploited in presidential campaigns. This could be due to the fact that 
the view is not clear, which made ElBaradei, who was a prospect candidate for presidential elections, decide to step down few months after freezing his campaign. Now that it has been formally announced that applications for presidential candidacy will start in March 2012, and that the elections is expected to take place before June 2012, the use of the Internet in the first democratic presidential elections ever in Egypt will be followed very closely and analyzed in depth.

It appears that the Internet was and is still playing an important role in influencing Egyptians from a political perspective, and that it can be used as a tool for promoting civic engagement. Internet users rely on the Internet in accessing political news and analysis, expressing opinions and monitoring the regime through publishing multimedia content. Smith and Rainie (2008) classify Internet's behavior in politics into 3 main activities: accessing news, communicating with others and being interested in campaign information and active in disseminating it. As such, Egyptians use the Internet in performing the first 2 activities.

One cannot deny the effect of the Internet on the happening of the Egyptian revolution. Even its censorship by the State Security Investigations (SSI) created an opportunity for youth groups to pass wrong messages about their intentions and meetings. Calls for demonstrations (started 18 months before the revolution) were transferred from the 'virtual to the tangible world', which were mostly efficient by social movements having a broad well-established existence (e.g., $6^{\text {th }}$ April Movement that has a strong online presence as well as physical presence in 24 of the 29 Egyptian governorates) (Ezbawy, 2012; Earl and Kimport 2008; Al-Sayyid 2011). Even during the 5 days of the Internet cutoff performed by the authorities from 28 January to 1 February 2011, young Egyptians living outside Egypt created a Facebook group reporting events worldwide (Ezbawy, 2012).
Egyptians had high expectations that the Internet will bring about a major change towards democracy (clearly perceived by the increasing number of Internet and social network users, and by the results of several studies indicating increasing interest in politics among Internet users after the revolution). Unfortunately however, one year after the revolution, the Internet's role is still falling behind expectations. Certainly, the Internet assisted the nation with the first steps into democracy through realizing a number of benefits on the ground, but was unable to build a critical mass capable of reaching the main objectives of the revolution and enabling activists to lead the political scene. Such fact was obvious in the first 'democratic parliament elections' that started in November 2011; relying mainly on the Internet in elections' campaigns from different youth fragmented entities was not successful in influencing the mass. They still miss different dimensions of political aspects in Egypt, 'in particular in the light of a very different configuration of political powers' under-estimating other powerful means to disseminate ideas and pass agendas, such as mosques (Tadros, 2012). Consequently, Islamist groups represent $75 \%$ of the elected members in the new Parliament, a far higher percentage than their contribution to the Internet-based politics. The political situation currently in Egypt can be described as a 'shallow' form of democracy reflecting mostly a propagandistic approach. There is still a long way to formulate a true democratic framework enabling people to commit change formally (Shoukry, 2012).

Shortcomings in the political status are due to several reasons in-line with the literature concerning the relation between the Internet and democracy in developing countries. First, Internet users constitute $25 \%$ of the population by educated groups since Egypt suffers from a high illiteracy rate. In addition, the Internet is providing a space for extremist groups and for electronic committees belonging to the authorities that 
are conveying messages against protesters and democratic movements. Second, as stated earlier, youth coalitions using the Internet are not yet combined into robust bodies. The third reason is attributed to the ruling regime following the same philosophy of the ousted one, is using the Internet as an additional channel to promote its ideas, and dissuade Internet content that does not. Thus, authorities are widely believed to be still imposing censorship on the Internet and are targeting Internet activists and jailing them, as was the case before the revolution. Lastly, youth activists are continuously dragged into various fights aiming to alter them from realizing the revolution objectives from the ruling regime and from political forces that 'claim ownership of the revolution' (Tadros, 2012), shifting their focus from constructing the required critical mass.

Nevertheless, the outlook is optimistic due to the high growth rate of Internet users and to the high percentage of youth in the Egyptian population; the best candidate to make change happen. Moreover, traditional media such as TV and newspapers are increasingly relying on online user generated content in seeking political news and facts, which widens Internet exposure covering even nonInternet users. In addition, since young political activists using the Internet do not yet possess a thorough knowledge in mobilization and building strong campaigns, they are definitely learning while practicing, and will gradually craft effective and creative new tactics. As Shoukry (2012) comments on the small percentage of youth activists who won in the first Egyptian parliamentary elections after the revolution: such results are based on the past, but the future will probably witness the foundation of new realities.

The Internet is definitely a potential mean for identity construction, which in turn mobilizes Civil Society leading to sociopolitical change (Habermas, 1996). Hence, Civil Society is presented with an unprecedented opportunity to formulate the
Internet in developing countries while Internet diffusion is continuously on the rise (Petrazzini and Kibati (1999). It is thus recommended for youth coalitions to minimize the gap between the Internet and the ground through a continuous scanning and recognition of public opinion leading to dynamic reshaping of unified online and offline strategies. Online information sharing and communication are not sufficient to realize political reform and to bring democratic changes in developing countries. The Internet should be considered a tool to support the creation of a physical environment for such transformation (Albirini, 2008). Thus, youth coalitions should reconsider using the Internet in collaborating with similar interest groups to form robust political entities.

\section{References}

Abdellah, M. \& Blair, E. (9 July 2010). “Online Protest on Egyptian's Death Draws Hundreds," Reuters. Online 13/11/2010 at http://www.reuters.com/article/idUSTRE66 84SU20100709

AbouElMaaref, D. (16 June 2010). 'Hayat of London: Political Movement Shrinking due to the Rise of Emergency's Martyr,' ElShorouk Newspaper. Online 5/11/2010 at http://www.shorouknews.com/ContentData. aspx?id=248670

Adamic, L. A. \& Glance, N. (2005). "The Political Blogosphere and the 2004 U.S. Election: Divided they Blog," Weblogging Ecosystem Workshop.

Adel, A. (11 June 2010). 'Thousand Members every hour. On Martyr of the Emergency Law's Facebook's Page,' ElShorouk Newspapers. Online 5/11/2010 at http://www.shorouknews.com/ContentData. aspx?ID=245518

Ahram Center for Political and Strategic Studies: 13-32.

Albirini, A. (2008). "The Internet in Developing Countries: A Medium of 
Economic, Cultural and Political Domination," International Journal of Education and Development using Information and Communication Technology (IJEDICT), 4(1): 49-65.

Al-Ghitany, M. (1-7 March 2008). "Facing Facebook," AlAhram Weekly Online $1 / 12 / 2010$ at http://weekly.ahram.org.eg/2008/895/eg5. htm

Al-Sayyid, Y. (2008). 'Blogging and Bloggers:Virtual Space Versus Non-Virtual Society,' [in Arabic], Arab Strategic Report 2007-08, Cairo.

Awad, M. (18 May 2010). "Egyptians Go Online to Seek Political Change," Reuters. Online $\quad 7 / 10 / 2010$ at http://www.reuters.com/article/idUSTRE64 H1P620100518

Azab, N. A. (2012). "The Role of the Internet in Shaping the Political Process in Egypt," The International Journal of ePolitics (IJEP), March 2012, in press.

Badawy, R. (1 February 2012). 'Ezzedine Shoukry: Choice of Muslim Brotherhood of Military, Revolution, or Salafis Determines the Ruling System,' An Interview with Ezzedine Shoukri, AlMasryAlyoum.

Bahnisch, M. (2006). 'The Political Uses of Blogs,' Chapter in a Book Entitled "Uses of Blogs", Peter Lang, New York.

BBC News (14 June 2007). "The Tech Lab: Dave Winer," Online20/10/2010 at http://news.bbc.co.uk/2/hi/technology/674 8103.stm

BBC News (30 March 2010). "ElBaradei Urges Reform: Your Emails," Online $15 / 9 / 2010$ at http://news.bbc.co.uk/2/hi/middle_east/85 94617.stm

Bichard, S. L. (1 July 2006). "Building Blogs: A Multi-dimensional Analysis of the
Distribution of Frames on the 2004 Presidential Candidate Websites," Journalism and Mass Communication Quarterly.

Boczkowski, P. J. (2004). Digitizing the News: Innovation in Online Newspapers, The MIT Press, Boston, USA.

Broad, W. (8 September 2010). "Mohamed ElBaradei," The New York Times. Online $15 / 9 / 2010$ at http://topics.nytimes.com/top/reference/ti mestopics/people/e/mohamed_elbaradei/in dex.html?scp=3\&sq=egypt $\% 20$ politics $\& s t=c s$ $\mathrm{e}$

Bruns, A. (2006). "The Practice of News Blogging," Chapter in a Book Entitled "Uses of Blogs". Peter Lang, New York, USA.

Carlson, M. (2007). "Blogs and Journalistic Authority," Journalism Studies, 8: 264-279.

Chambers, S. \& Kopstein, J. (2001). “Bad Civil Society,” Political Theory, 29(6): 837-865.

Christensen, H., Griffiths, K. \& Evans, K. (2002). E-Mental Health in Australia: Implications of the Internet and Related Technologies for Policy, Canberra, Commonwealth Department of Health and Ageing.

Clark, H. H. \& Brennan, S. E. (1991). Grounding in Communication, Chapter in a book entitled "Perspectives on Socially Shared Cognition". American Psychological Association,Washington DC, USA.

Coleman, S. (2005). "Blogs and the New Politics of listening," The Political Quarterly, 76(2): 272-280.

Crespo, R. (2007). "Virtual Community Health Promotion," Preventing Chronic Disease, 4: 12.

Dean, J. (2003). "Why the Net is Not a Public Sphere," Constellations, 10(1): 95-112. 
Downey, J. \& Fenton, N. (2003). "New Media, Counter Publicity and the Public Sphere," New Media \& Society, 5(2): 185-202.

DWSMG (Nov. 2008). “Barack Obama's Ultimate Guide to Marketing: How he Used Internet and Social Media to Become President-Elect," Online 27/9/2010 at http://www.dwsmg.com/barack-obamamarketing-guide.html

Earl, J. \& Kimport, K. (2008). "The Targets of Online Protest," Information, Communication and Society, 11(4): 449-72.

Editor and Publisher (24 February 1996). 'Number of Papers withOnline Edition Tripled,'.

ElShorouk Newspaper (11 June 2010). 'Facebook's Page (Martyr of the Emergency Law) has Almost 4000 Members in One Hour,' Online 5/11/2020 at http://www.shorouknews.com/ContentData. aspx?id=245396

ElShorouk Newspaper (15 June 2010). In Video. 'Witnesses Blow Ministry of Interior's Statement about the Murder of Martys of the Emergency Law,' Online 5/11/2010 at http://www.shorouknews.com/ContentData. aspx?id=248338

Ezbawy, Y. A. (2012). “The Role of the Youth's New Protest Movements in the January 25th Revolution," IDS Bulletin, 43(1): 26-36.

Facebook Press Room (9 October 2010) Online $\quad 9 / 10 / 2010 \quad$ at http://www.facebook.com/press/info.php?s tatistics

Farrell, H. \& Drezner, D. W. (2008). "The Power and Politics of Blogs," Public Choice, 134(1): 1-2.

Ghuitas (22 February 2011). 'First Scientific Analysis Monitoring Revolution's Facts through the Internet,' AlAhram Newspaper 2011.
Gillmor, D. (11 April 2003). 'Making the News,' E-Journal: News, Views, and a Silicon Valley Diary. Online 5/9/2010 at http://www.Weblog.siliconvalley.com/colu $\mathrm{mn} /$ dangillmor/archives/000924.shtml

Goldfarb, Z. (3 February 2007). 'Facebook Flexes Political Might,' The Washington Post, USA.

Habermas, J. (1974). 'The Public Sphere,' In the Information Society Reader. Routledge, New York, USA.

Habermas, J. (1996). Between Facts and Norms: Contributions to a Discourse Theory of Law and Democracy, Cambridge: Polity Press.

Information and Decision Support Center (IDSC) (2005). "The Effect of the Internet on Youth in Egypt and the Arab World: A critical Study," Online 20/6/2011 at http://www.idsc.gov.eg/Upload/Documents /103/Influence_Youth_Egyp_Arab\%20World. pdf

Kamel Boulos, M. N.\& Wheeler, S. (2007). "The Emerging Web 2.0 Social Software: An Enabling Suite of Sociable Technologies in Health and Health Care Education," HealthInformation and Libraries Journal, 24: 2-23.

Kerbel, M. R. \& Bloom, J. D. (2005). "Blog for America and Civic Involvement," Press/Politics,10: 3-27.

Khiabany, G. (2009). "Iranian Media: The Paradox of Modernity," Routledge, NY, USA.

Lasica, J. D. (2002). 'Weblogs: A New Source of News,' In "We've Got Blog: How Weblogs are Changing Our Culture". Ed.RodzvilleJ. Perseus Publishing, Cambridge, MA, USA.

Lefebvre, R. C. (2007). “The New Technology: The Consumer as Participant Rather Than Target Audience," Social Marketing Quarterly, 13(3): 31-42. 
Lunat, Z. (2008). "The Internet and the Public Sphere: Evidence from Civil Society in Developing Countries," The Electronic Journal on Information Systems in Developing Countries EJISDC 35(3): 1-12.

Martin, S. E. \& Hansen, K. A. (1998). Newspapers of Record in a Digital Age: from Hot Type to Hot Link, Westport, CT: Praeger.

Metcalf, A., Blanchard, M., McCarthy, T. \& Burns, J. (2008). 'Bridging the Digital Divide: Utilising Technology to Promote Social Connectedness and Civic Engagement amongst Marginalised Young People,' Journal of Community, Citizen's and Third Sector Media and Communication, issue 4(8): 1-15.

Metzger, M. J., Flanagin, A. J., Eyal, K., Lemus, D. R. \& McCann, R. M. (2003). 'Credibility for the 21st Century: Integrating Perspectives on Source, Message, and Media Credibility in the Contemporary Media Environment,' In "Communication Yearbook 27". Ed. Kalfleisch P. J., Mahwah, Lawrence Erlbaum Associates, New Jersey, USA.

Milner, H. V. (2006). “The Digital Divide: The Role of Political Institutions in Technology Diffusion," Comparative Political Studies, 39(2): 176-99.

Ministry of Communication and Information Technology (MCIT) (February 2011). "ICT Indicators in Brief - February 2011 Monthly Issue," Online 10/6/2011 at http://mcit.gov.eg/Upcont/Documents/ICTi nBriefFeb2011-E.pdf

Molina, A. (1997). "Issues and Challenges in the Evolution of Multimedia: The Case of the Newspaper," Futures, 29(3): 193-211.

Nardi, B. A., Schiano, D. J., Gumbrecht, M. \& Swartz, L. (2004). "Why we Blog?," Communications of the ACM, Special Issue: The Blogosphere, 47(12): 41-46.

Norris, P. (2001). "Digital Divide: Civic Engagement, Information Poverty, and the
Internet Worldwide," Harvard University, Cambridge: University Press, Massachusetts.

Papacharissi, Z. (2002). "The Virtual Sphere: The Internet as a Public Sphere," New Media \& Society, 4(1): 9-27.

Peng, F. Y., Them, N. I. \& Hao, X. (1999). 'Trends in Online Newspapers: A Look at the US Web,' Newspaper Research Journal, 20(2): 52-63.

Petrazzini, B. \& Kibati, M. (1999). "The Internet in Developing Countries," Communications of the ACM, 42(6): 31-36.

Schiano, D., Nardi, B., Gumbrecht, M. \& Swartz, L. (2004). "Blogging by the Rest of Us," CHI Extended Abstracts 2004: 11431146.

Smith, A. \& Rainie, L. (2008). "The Internet and the 2008 Election," Online 4/2/2012 at http://pewinternet.org/ /media//Files/Rep orts/2008/PIP_2008_election.pdf.pdf

Stromer-Galley, J. \& Baker, A. (2006). "Joy and Sorrow of Interactivity on the Campaign Trail: Blogs in the Primary Campaign of Howard Dean," In "The Internet Election: Perspectives on the Web in Campaign2006", Ed. Williams A. and Tedesco, J., Rowman and Littlefield, Lanham, MD, USA.

Tadros, M. (2012). "The Pulse of the Arab Revolt," IDS Bulletin, 43(1): 1-15.

Trammell, K. (2006). 'The Blogging of the President,' In "The Internet Election: Perspectives on the Web in Campaign 2006", Ed.Williams A. and Tedesco, J., Rowman and Littlefield, Lanham, MD, USA.

Trippi, J. (2004). 'The Revolution will not be Televised,' Harper Collins, New York, USA.

Westling, M. (2007). "Expanding the Public Sphere: The Impact of Facebook on Political Communication," Online 20/10/2010 at http://www.thenewvernacular.com/projects /facebook_and_political_communication.pdf 
Williams, W. S. (1998). "The Blurring of the Line between Advertising and Journalism in the On-Line Environment," In "The Electronic Grapevine: Rumor, Reputation, and Reporting in theNew On-line Environment", Ed. Borden, D. and Harvey, K., Erlbaum, Mahwah, New Jersey, USA.

Wyn, J., Cuervo, H., Woodman, D. \& Stokes, H. (2005).'Young People, Wellbeing and Communication Technologies,' VicHealth, Melbourne, Australia. 